Journal of Information Management and Business Review

Vol. 2, No. 4, pp. 162-172, Apr 2011

\title{
Brand Categorization Process for Staple Goods: Comparison between Rural and Urban Customers
}

\author{
${ }^{1}$ Manash Pratim Kashyap*, 2Dibyojyoti Bhattacharjee \\ 1,2Department of Business Administration, Assam University, Silchar,, Assam, India \\ *kashyap.manashaus@gmail.com
}

\begin{abstract}
The main purpose of the paper is to measure and compare the awareness set, consideration set and choice set of rural and urban population. The brand categorization process in an important aspect of consumer behavior and is useful in understanding how a consumer chooses a particular brand. The focus of this work is to compare the brand categorization process of rural and urban consumers. The consumer's choice process, on some selected staple goods viz. rice, salt, edible oil and tea for rural and urban customers are considered. The study reaches the conclusion that the awareness set size and the consideration set size does not differ significantly for urban and rural consumers but the choice set size differs for rice. For salt and edible oil the rural customers seems to be more aware though there consideration set size and choice set size do not show any significant difference. However, for tea the urban folk have a bigger consideration set and choice set compared to the rural population.
\end{abstract}

Key words: Awareness set, Consideration set, Rural Marketing, choice set, choice

\section{Introduction}

Due to globalization one of the major focuses of research in marketing is the understanding and prediction of consumer's brand choice behaviour. The design and implementation of various strategies of marketing require the understanding of the competitive patterns among brands which is defined as the explanation of consumer brand preferences in terms of attributes (Elrod and Keane, 1994). The concept of brand categorization process begins with the universal set (Narayana and Markin, 1975). They define universal set as all the available brand exists within the product class at any given time. This universal set of brands will fluctuate overtime as new brand are introduced and unsuccessful brand are withdrawn. In the point of consumer, it is observed that the brands are available in market are usually divided into two category that the brands of which customer is aware and those of which he/she is not aware (Roberts and Lattin, 1991). So, awareness set is formed by awareness or known brands of a particular products or services by a customer. Again, from awareness set there are certain brands or services that a consumer would consider for purchasing is known as consideration set and remaining brands are not considered. Consumer purchase decision always restricted to the brands products included in the consideration set. So, formation of consideration set is a preliminary stage of pre-choice decision making (Ratneswar and Shocker, 1991).

Roberts and Lattin, (1991) termed consideration set as evoked set. Roger and Hacfen (2008) define choice set which is a deal with specifying the objects of choice that enter an individual preference ordering and represent the endogenous arguments that he/she optimizes with respect to consumers choice strategies, brand loyalty and changes in market share that are independent of brand evaluation can be measured by using consideration set (Kardes et. al, 1993; Nedungi, 1990). However, consumers consideration set creates an opportunity for brand managers to increase a brand market share (Desai and Hoyer, 2000). The consumer consumption situation may be influence by formation of consideration set. The preference of consumer may create consideration set that consist of brands or services that are easy to compare or that increase the likelihood an optimal alternative is retained for further consideration (Hauber and Kline ,1991; Wright 1975). Siddarth et. al (1995) define the needful of choice set that these set across the consumers provides a series of managerial insights regarding the competitive position of a brand. They give an example by comparing the market share position of competing brands with their choice set share position.

This paper looks into the comparison of different sets of consumer choice process by considering staples goods. According to Shari waters, About.com defines staple good as products purchase regularly and out of necessity. Traditionally, these items have fewer markdowns and lower profit margins. While price shifts may 
raise or lower demand for certain kinds of products, the demand for staple goods rarely changes when prices change. Kotler (2002) defines staple good as those goods that consumer purchase in regular basis. According to gluetext.com defines staple goods as consumer goods that are bought often and consumed routinely. The dynamic change of market place has increased competition of the global economy and has expanded the role of brands (Sharma and Srivastava, 2008). But the consumer behaviour in the rural and urban area definitely differs from each other. Because of differencing culture, purchasing power, available options and so on. Rural market is basically depends on agricultural products, local products like home made oil, unbranded rice, tea directly from the garden etc. Most of the people in rural area produced rice, oil etc. at his/her own plough land, kitchen garden etc. So, it is important to see how the brand categorization process differs between rural and urban area. In this paper, an attempt is been made to measure the difference in the brand categorization process due to some selected staple goods between rural and urban customers. The staple goods considered are rice, tea, salt and edible oil. The study shall provide the reader with an idea about the awareness level of the rural and urban customers with respect to the goods under consideration along with the other features of the brand categorization process.

The objectives of the study are:

1. To compare the awareness set, consideration set and choice set of rural and urban customers for rice.

2. To compare the awareness set, consideration set and choice set of rural and urban customers for salt.

3. To compare the awareness set, consideration set and choice set of rural and urban customers for edible oil.

4. To compare the awareness set, consideration set and choice set of rural and urban customers for tea.

\section{Review of Literature}

A review of literature concerning consumer's brand categorization process has been provided by the researcher. Howard and Sheth (1969); Campbell (1969); Jarvis and Wilcox (1973) shows that how and why a consumer move to simplify and limit the number of brands that are considered in a purchase decision is an important concern to the marketing research. Belonax (1979) study the consideration set as "Which brands are acceptable for purchase by a consumer?" Narayana and Markin (1975) define consideration set as "Which brands the consumer considers buying?" Wright and Barbour (1977) define consideration set as "Brands that a consumer will consider". Klenosky and Rethans (1988) considered consideration set as "Which brands the consumer would consider for buying if consumer faced with immediate purchase decision?" Brisoux and Laroche (1980) focused consideration set as "Which brands the consumer considered for a specified consumption situation?" Church, Laroche and Rosenblatt (1985) studied that "Which brand the consumer would buy if buying today, and other brands the consumer willing to buy if the first choice is not available?" Maddox et al. (1978) studied that "Which brand was chosen in the last purchase incident and if more than one brand was considered, brands about which the consumer reported?"

One of the important aspects of consumer behaviour is "consideration sets". Consideration sets gives us the purchasing behaviour of the customer. Howard (1963) perceived that consumer consider only a few alternatives instead of the total set when they simplify and managed their brand choice. He categorized the total sets into an awareness set and unawareness set. Howard and Sheth (1969) give another definition of consideration set. They define that the set which consists of a limited number of brands that are actively taken into account in the choice process of the consumers. Nedungadi (1990) define consideration set as due to consumer limitation on information processing abilities and hence the customer cannot make explicit utility comparisons across all the brands so his/her processing task the consumer limits converted to subsets. When a customer makes an explicit utility comparison or cost benefit trade before he/she makes his/her brand choice decision from the all brands in the product category is termed as Consideration sets (Mehta et.al 2003). According to Schiffman and Kanuk (2007), Consideration sets is the specific brand (models) a consumer considers in making a purchase within a particular category.

Guadangi and Little (1983) proposed an empirical model as a multinomial logit model of the consumer brand choice. He took 100 households and observed 32 weeks of purchased of regular ground coffee. He found highly significance of the exploratory variables of brand loyalty and size loyalty. Troye (1984) studied that 
multiple operational definitions of evoked sets. He found little evidence of the impact of same differences. Hauser and Wernerfelt (1990) developed a model which maximized the utility of brand that the consumer finds it optimal to behave in a way that consistent with the construct of the consideration set. Roberts and Lattin (1991) developed a model of consideration set composition taking the assumption that maximized the utility of the consumer which is used to forecast individual consideration of the three new products. They defined consideration set as "the brands that consumer would consider buying in the near future". Brown et.al.,(1992) measured the consideration set by considering several operational definition of consideration set and found empirical differences within the operational definitions.

Chintagunta (1992) estimated a multinomial probit model of brand choice using method of simulated moments. Desarbo and Jedidi (1995) proposed a new multidimensional scaling methodology (MDS) devised to spatially represent the preference intensity collected over the consumer's consideration set. Vroomen et al., (2000) made brand choice by making consideration set in two step process using Artificial Neural Network (ANN). They assumed that the unobserved hidden layer in an ANN corresponds with such a consideration set. Cullen and Kingston (2009) studied the attributes of the rural and urban consumer choice and attitudes toward the selection and purchase of new food product. They find that urban consumers are more responsive toward new product and the modes of influence have a greater impact on the urban market segment.

\section{Conceptual frame work}

From the above discussion it is clear that the study of brand categorization process has been a prime area of investigation. Most of the studies related to consideration set centres around the other convenience goods. However, this paper looks into the staple goods that are consumed in a greater extent by both rural and urban customers. Consideration sets are the subset of all those brands or models which are considered by the Consumer with respect to certain constrains from all the brands in the product category. But consumers have limited information about the brands awareness of a particular product category. So it is necessary to divide all the brand of a particular product category into (i) Awareness set; and (ii) Unawareness Set. Shocker et al. (1991) notice that Awareness or knowledge set consists of the subset of items in the universal set of which, for whatever reason, a given consumer is "aware". Consideration sets is a part of the Awareness Sets according to the limitation of the consumers awareness. Narayana and Markin (1975) expanded the awareness set into three subsets viz. inept set, inert set and evoked set.

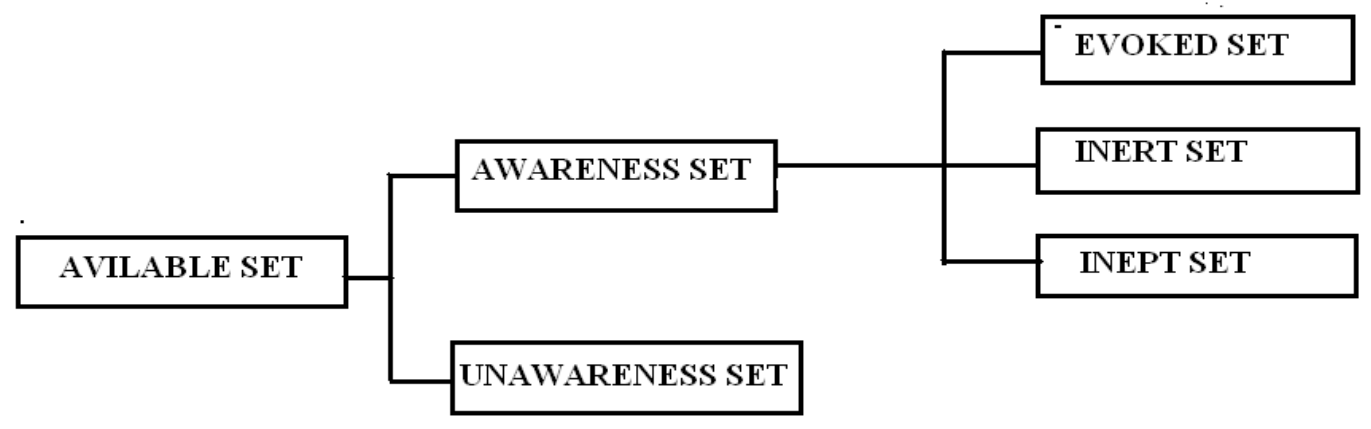

Figure 1. Narayana and Markin model (1975)

Howard (1977) gives concept of the brand categorization process as "the subset of brands that consumer considers buying out of the set of brands that he or she is aware of in a product class." Laroche and Rosenblatt (1983) observed that the model of Howard (1977) is essentially a simplification of the consumer's decision making process when motivated to purchase a product. They highlighted that a consumer's evoked set develop from the routinized response behaviour. Routinized response behaviour means a small amount of time and required information is necessary to make the actual purchase choice. Howard (1977) divided the total set as awareness set and unawareness set. From the consumer routinized response behaviour he found the evoked set from the awareness set. 


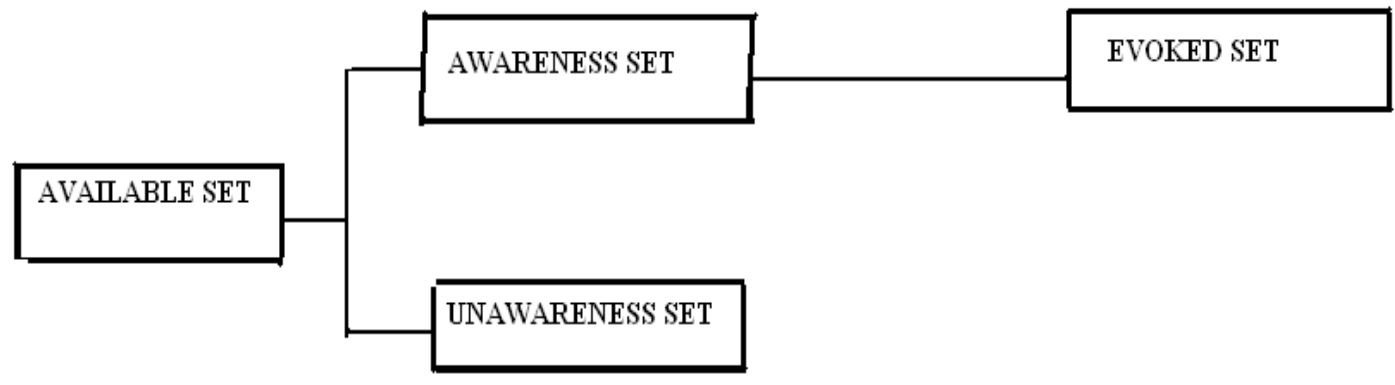

Figure 2. Howard model (1977)

Schiffman and Kanuk (2007) define a set as inept set consists of those brands that consumer excludes from purchase consideration because the brands are felt to be unacceptable. They also define inert set as the set which consist of brands the consumer is indifferent toward because they are perceived as not having any particular advantages i.e the brands in the inert set are neither accepted nor rejected, they are neutral. Belonax (1979) define consideration set as the set acceptable to the consumer. Myers (1976) focus that the definition given by Belonax (1979) and definition given by Howard and Sheth (1969) are not same. Brisoux and Laroche (1980) divided awareness sets into two groups viz. processed set and unprocessed set (foggy set). They define processed and unprocessed set as: "consumer asses the brands in the process set on at least one salient attribute and in turn, form their opinions (i.e. attitudes, confidence levels and purchase intentions). Conversely, brands in the unprocessed (foggy set) are not evaluated on any salient attribute. The consumer may even forget about the brand, thus placing it in foggy set." They further divided processed sets into three sub sets viz. consideration Set; hold Set; reject Sets. Hold set may contain that brands of product or services that consumer neither likes nor dislikes. This definition is similar to the inert set as defined by Schiffman and Kanuk (2007). Again, the reject set contains those brands or services of a product that a consumer considered as unacceptable purchase alternatives and consumer hold negative attitudes towards these brands.

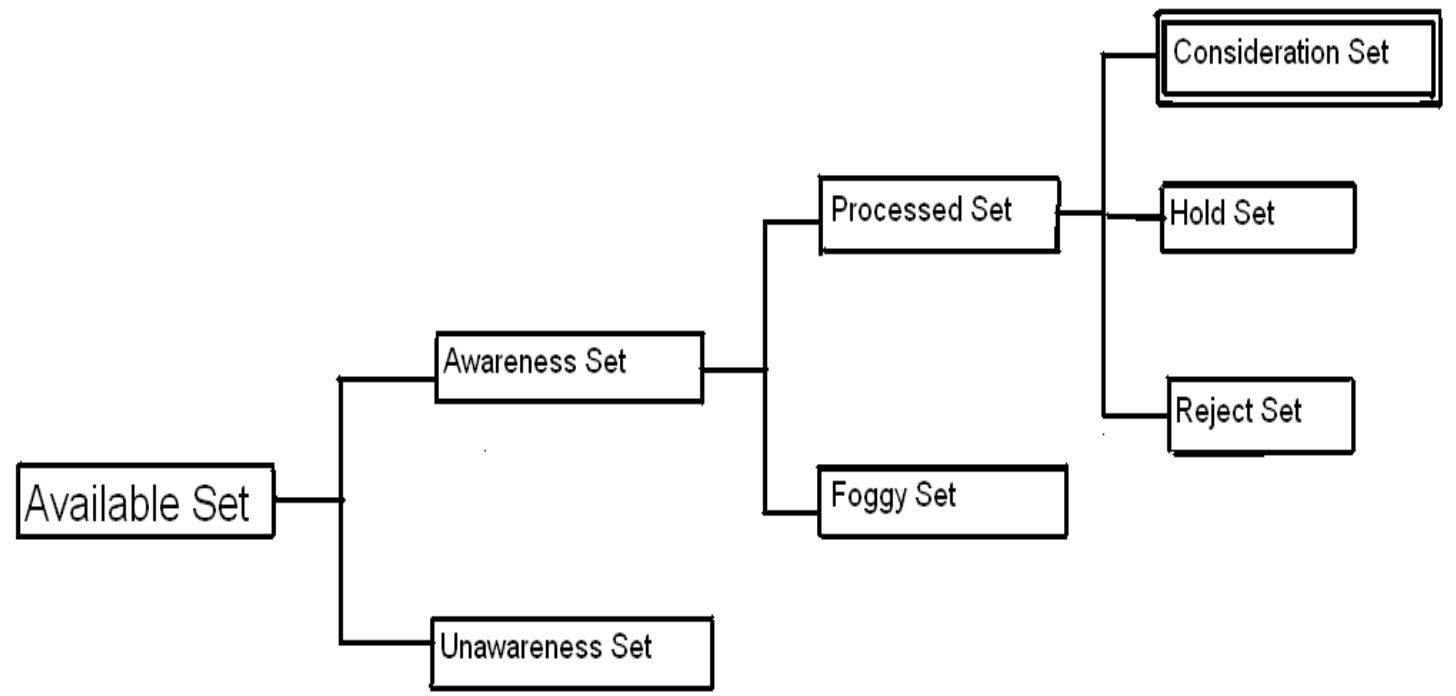

Figure 3. Brisoux-Laorche model of Brand Categorization (1980)

There are four stages that a consumer choice brand or variety of a particular product. The first stage is known as universal set which is defined as a set of all brands of a particular product or services that could be obtained by any consumer under any condition. This stage is the starting point of a consumer that he/she made the decision what to buy or not to buy. The second stage is known as awareness set that consist of all 
the brands that a consumer is aware and he/she find the goals or objectives. The third stage is formation of consideration set. The fourth stage is defined by Shocker et. al. (1991) as choice set. They noticed that the consideration set is dynamic in nature. So it is necessary to define another set which is very closely related in more static terms and he defines choice set as the final consideration set. He finds that this set contains fewer but more highly differentiated product or services which are select from the consideration set. From this choice set a consumer choice his/her particular product or services.

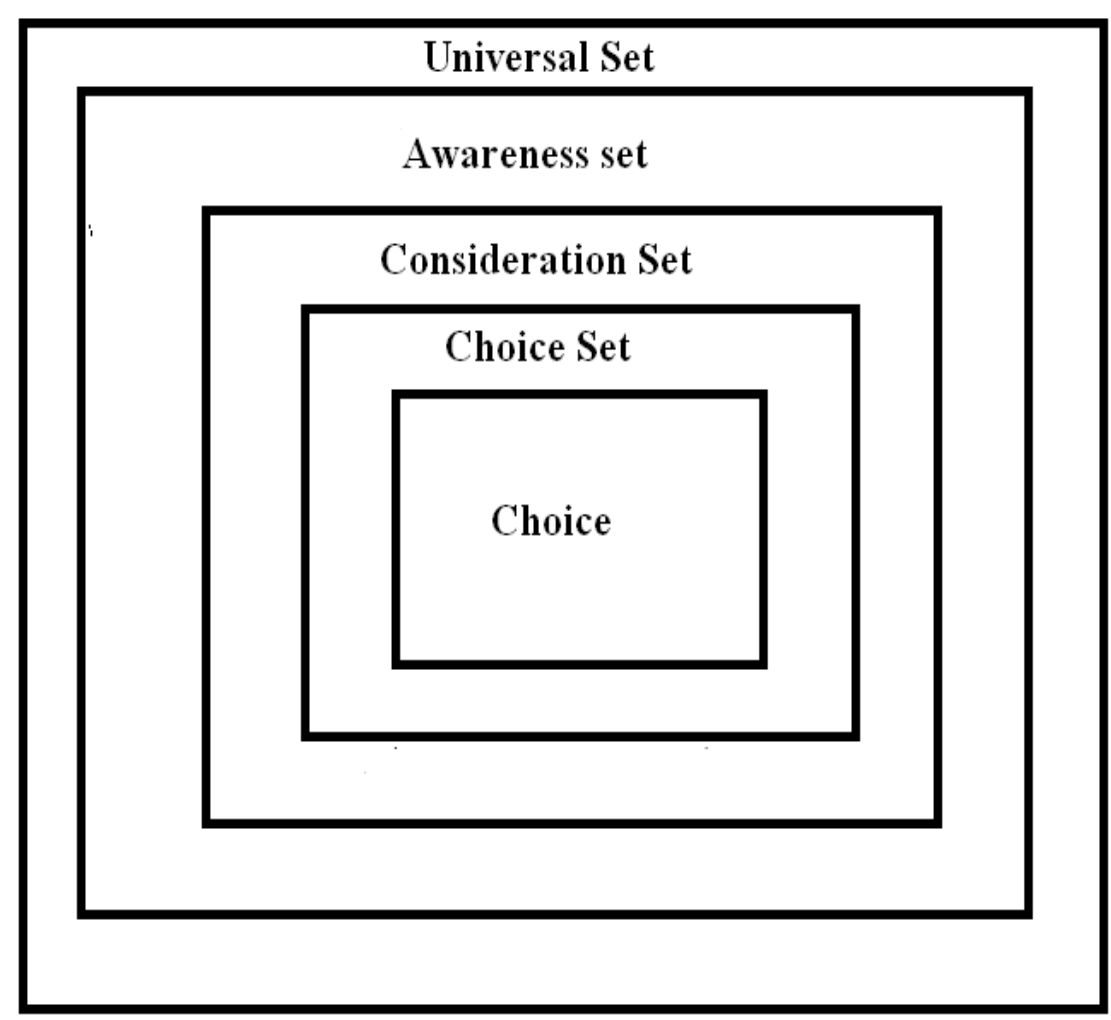

Figure 4. A Model for Brand Categorization Process

\section{Hypotheses of the Study}

Based on the review of literature and discussion of the conceptual framework the following hypotheses that are considered for the study for the staples goods viz. rice, salt, edible oil and tea:

$\mathrm{H}_{01}$ : There is no significant difference between the awareness set of rural and urban population for the goods under consideration.

$\mathrm{H}_{02}$ : There is no significant difference between the consideration set for rural and urban population for the goods under consideration.

$\mathrm{H}_{03}$ : There is no significant difference between the choice set of rural and urban population for the goods under consideration.

\section{Methodology}

The methodology of the study which is adopted for compare the awareness set, consideration set and choice set of consumer's brand categorization process for rural and urban population considering some selected staples goods viz. rice, salt, edible oil and tea. For the purpose of comparison, we consider the following question:

1. What are the brands/varieties known to you?

2. What are the brands you don't purchase, but are liked by you?

3. What are the types of brands of product purchased in last occasion? 
The question "What are the brands/varieties known to you?" would result into the "awareness set" of the respondent, because the above question focuses the consumer's awareness or knowledge of brands or services of a particular product. The question "What are the brand's you don't purchase, but are liked by you" would produce the "Consideration set" after adding the question "What are the types of brands of the given product purchased in last occasion?" Since, the question gives that what are the brands a consumer likes from the awareness set and what are the brands of the given product he choice are together termed as consideration set. The question "What are the types of brands of product purchased in last occasion?" is considered as "Choice Set". After defining the awareness set, consideration set and choice set, a comparison is done between rural and urban of these sets are done by taking the above mentioned staples goods.

\section{Sampling and Data Consideration}

The area from which the data is collected is Cachar district of south Assam, India. The district covers an area of 3786 square kilometres with 273694 households. Out of which 21575 households are located in urban area and the rest are rurally located. Since the study involves both rural and urban customers, so a sample of households of size 194 from urban area and 196 from rural area are selected. The sample size is calculated with 95 percent confidence level and a confidence interval of 5 percent. The sampling is performed separately for rural and urban area. In the said district there are 1020 villages. From which 52 villages were selected i.e. one out of every twenty village. From the selected 51 villages, a total of 196 households are selected randomly, in such a way that the number of household selected from each village remains proportional to the number of households in that village. There are only two towns in the district which are divided into 28 and 10 municipal wards respectively. From each of the wards, households are selected randomly taking the total number of households selected from urban area to 194. In this case as well, the number of households selected from each of the municipal wards is proportional to the total number of households in that ward. The available information was loaded to SPSS 17.0 and accordingly the data was analyzed.

\section{Analysis and Findings of the Study}

This study compares the brand categorization process of rural and urban consumers and evaluates the sizes of the awareness set, consideration set and choice set for some select staples goods viz. rice, salt, edible oil and tea. Table 1, highlights the analysis for the product rice. It is observed that the mean awareness set size and the consideration set size does not differ significantly for urban and rural consumers. But, the choice set size is found to differ significantly between rural population and urban population. This gives an indication that the urban customers purchase more verities of rice compared to the rural customers. Table 2 provides the analysis of the brand categorization process for the product salt. The average awareness set size is in favour of the rural customers implying that they are more aware of the different brands of salt compared to urban people. However, the consideration set size and the choice set size of the customers of rural and urban area does not differ significantly.

Table 3 focuses the analysis of the brand categorization process for the product edible oil. Here also, the average awareness set size is in larger in case of the rural customers, though the consideration set size and the choice set size does not differ significantly from urban customers. The brand categorization process of consumers for the product tea is considered in Table 4. This is the only product in which a significant difference is visible in the consideration set. The urban customers consider several brands of tea before the actual purchase, compared to their rural counterpart. As different tea gardens are located in the rural areas so the population tends to take tea leaves available from gardens, and prepare tea after undergoing some domestic processing. This may also be responsible for a larger average choice set for tea amongst urban consumers compared to rural consumers, though the difference is not statistically significant.

Thus, the knowledge of the different brands for the products considered is not less in the rural areas. In the contrary the rural folk are aware about more number of brands of products. In case of purchasing decisions the rural folk might have compromised with quality of the product (which was not in the purview of this study) but not with the number of varieties of the products in most cases. 
Table 1: Average Size of Different Sets of Brand Categorization Process of Customers in Rural and Urban Population for the Product Rice

\begin{tabular}{|c|c|c|c|c|c|c|}
\hline \multirow[t]{2}{*}{ S/N } & \multirow[t]{2}{*}{ Sets of Products } & \multicolumn{2}{|c|}{ Averages } & \multirow{2}{*}{$\begin{array}{c}\text { z- } \\
\text { value }\end{array}$} & \multirow{2}{*}{$\begin{array}{c}P \text { - } \\
\text { value }\end{array}$} & \multirow[t]{2}{*}{ Comment } \\
\hline & & Rural & Urban & & & \\
\hline 1 & Awareness Set & 4.24 & 4.28 & -0.062 & 0.475 & $\begin{array}{l}\text { The awareness set size of the urban } \\
\text { customers for rice not differs } \\
\text { significantly from that of rural } \\
\text { customers. }\end{array}$ \\
\hline 2 & Consideration Set & 1.64 & 1.92 & -0.904 & 0.183 & $\begin{array}{l}\text { The consideration set size of the } \\
\text { urban customers for rice not differs } \\
\text { significantly from that urban } \\
\text { customer. }\end{array}$ \\
\hline 3 & Choice Set & 0.80 & 1.04 & -2.640 & $0.004^{*}$ & $\begin{array}{l}\text { The choice set of the urban customers } \\
\text { for rice differs significantly from that } \\
\text { of rural customers. This gives an } \\
\text { indication that urban customers } \\
\text { purchase more varieties of rice } \\
\text { compared to the rural customers. }\end{array}$ \\
\hline
\end{tabular}

“*” significant at $5 \%$ level of significance.

Table 2: Average Size of Different Sets of Brand Categorization Process of Customers in Rural and Urban Population for the Product Salt

\begin{tabular}{|c|c|c|c|c|c|c|}
\hline \multirow[t]{2}{*}{$\mathbf{S} / \mathbf{N}$} & \multirow[t]{2}{*}{ Sets of Products } & \multicolumn{2}{|c|}{ Averages } & \multirow{2}{*}{$\begin{array}{c}\mathrm{z}^{-} \\
\text {value }\end{array}$} & \multirow[t]{2}{*}{$P$-value } & \multirow[t]{2}{*}{ Comment } \\
\hline & & Rural & Urban & & & \\
\hline 1 & Awareness Set & 3.00 & 1.64 & 5.155 & $0.000^{*}$ & $\begin{array}{l}\text { The size of the awareness set of the } \\
\text { urban customers for salt differs } \\
\text { significantly from the rural } \\
\text { customers. This gives that rural } \\
\text { customers have more aware about } \\
\text { different brands of salt than the } \\
\text { urban customer. }\end{array}$ \\
\hline 2 & Consideration Set & 1.08 & 1.00 & 1.445 & 0.074 & $\begin{array}{l}\text { The size of the consideration set of } \\
\text { urban customer not differs } \\
\text { significantly from that rural } \\
\text { customer. }\end{array}$ \\
\hline 3 & Choice Set & 1.08 & 1.00 & 1.445 & 0.074 & $\begin{array}{lccc}\begin{array}{l}\text { The size of choice } \\
\text { customers }\end{array} & \begin{array}{c}\text { sees } \\
\text { does }\end{array} & \text { not } & \text { differ } \\
\text { significantly } & \text { from } & \text { their } & \text { rural } \\
\text { counterpart. } & & & \end{array}$ \\
\hline
\end{tabular}

“*” significant at $5 \%$ level of significance. 
Table 3: Average Size of Different Sets of Brand Categorization Process of Customers in Rural and Urban Population for the Product Edible Oil

\begin{tabular}{|c|c|c|c|c|c|c|}
\hline \multirow[t]{2}{*}{ S/N } & \multirow[t]{2}{*}{ Sets of Products } & \multicolumn{2}{|c|}{ Averages } & \multirow{2}{*}{$\begin{array}{c}\mathrm{z-} \\
\text { value }\end{array}$} & \multirow[t]{2}{*}{$P$-value } & \multirow[t]{2}{*}{ Comment } \\
\hline & & Rural & Urban & & & \\
\hline 1 & Awareness Set & 4.56 & 3.12 & 3.016 & $0.001^{*}$ & $\begin{array}{l}\text { The awareness set size of the rural } \\
\text { customers differs significantly from } \\
\text { that of urban customers. This result } \\
\text { highlighted that rural customers } \\
\text { have more aware of the brands of } \\
\text { edible oil than the urban customer. }\end{array}$ \\
\hline 2 & Consideration Set & 2.08 & 1.76 & 1.299 & 0.0968 & $\begin{array}{l}\text { The consideration set size of the } \\
\text { urban customer not differs } \\
\text { significantly from that rural } \\
\text { customer. }\end{array}$ \\
\hline 3 & Choice Set & 1.56 & 1.56 & 0.00 & 1.000 & $\begin{array}{l}\text { The choice set size of urban } \\
\text { customers not differs significantly } \\
\text { from the rural customers. }\end{array}$ \\
\hline
\end{tabular}

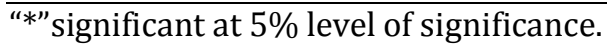

Table 4: Average Size of Different Sets of Brand Categorization Process of Customers in Rural and Urban Population for the Product Tea

\begin{tabular}{|c|c|c|c|c|c|c|}
\hline \multirow[t]{2}{*}{$\mathbf{S} / \mathbf{N}$} & \multirow[t]{2}{*}{ Sets of Products } & \multicolumn{2}{|c|}{ Averages } & \multirow{2}{*}{$\begin{array}{c}\text { z- } \\
\text { value }\end{array}$} & \multirow{2}{*}{$\begin{array}{c}P- \\
\text { value }\end{array}$} & \multirow[t]{2}{*}{ Comment } \\
\hline & & Rural & Urban & & & \\
\hline 1 & Awareness Set & 3.04 & 3.36 & -0.580 & 0.28 & $\begin{array}{l}\text { The sizes of the awareness set between } \\
\text { the urban customers and rural customers } \\
\text { do not differ significantly. }\end{array}$ \\
\hline 2 & Consideration Set & 1.16 & 1.60 & $-1.718^{*}$ & 0.042 & $\begin{array}{l}\text { There is a significant difference between } \\
\text { rural and urban customers. It gives an } \\
\text { indication that urban customers consider } \\
\text { more brands of tea than rural customers. }\end{array}$ \\
\hline 3 & Choice Set & 0.80 & 0.96 & -1.309 & 0.095 & $\begin{array}{l}\text { The sizes of the choice set between urban } \\
\text { and rural customers are not significantly } \\
\text { different. }\end{array}$ \\
\hline
\end{tabular}

“*”significant at $5 \%$ level of significance.

\section{Scope and Limitations of the study}

One important aspect of the study is to understand the brand categorization processes of customer that is how a customer selects a brand or varieties from the universal set. This study emphasized on marketing comparisons of urban and rural customers and their impact on staples goods. This study enables us to give the competitive structures of different brands of a few product categories. The products which are considered for the study are relatively homogeneous and fall under the category of staple goods, this has the characteristics that the prices of the products are low, frequently purchased and non durable. It is obvious that homogeneous products provide lower variability. The size of the sample considered for our study is too small. So there has been chance of error or bias. At the time of conducting the survey it is observed that most respondents find it difficult to recall the brand names that are members of their consideration set and awareness set. Thus the respondents may be aware of several brands which they are unable to recall at the time of survey. 


\section{Conclusion}

The brand categorization process of a consumer includes the awareness set, consideration set and choice set. This study focuses on the comparison of the brand categorization process of rural and urban consumer considering the staples goods. This study shows that sizes of awareness set of consumer for both the rural and urban area are same for the product rice and tea. But in case of the consideration set, it is observed that sizes of the consideration set for all the products considered for the study are almost same for rural and urban population. The size of the choice set for rural and urban is same for the product salt, edible oil and tea. In case of rice the awareness set are almost similar for both rural and urban consumer, but their choice set are different. This result gives that another future study for different choice set of both rural and urban consumer. It is observe that the size of the awareness set are different for the product edible oil and salt between rural and urban customer, but their choices are almost same. This study is useful when the brand categorization process of consumers has been well supported for a service product and in an extensive problem solving situation.

The study gives an idea about the awareness set, consideration set and choice set of rural and urban customers. For an individual, who is interested in starting a grocery store, the awareness of rural and urban customers toward the different brands of products can be known. This study allows the individual to know the brands which is considered by the customers while buying the product. From the consideration set the customers make his/her choices. By this way the individual will be aware of the choice of his customers. If the individual performs this study taking the product with his interest he/she will benefit to identify the customer choice towards the brands by considering the brand categorization process. In addition to this, the study may be of importance to a particular company's marketing individual as it can be identified at what stage in the brand categorization process a given brand is getting rejected. For example, if a brand cannot even find a place in the awareness set of the corresponding product it implies that not many people know about it and also that it is not in display in any of the stores, i.e. more promotional activities should follow to make people aware of the product. Similarly, the marketer may come around with several other conclusions related to the different stages of brand categorization of products. The study should not be generalized for the entire country as it is been performed in the North Eastern part of India. In this part of the globe, there is a huge production of tea and hence the market is flooded with several brands of tea both local and branded. Other parts of the country may not have such an excessive supply with respect to tea. So far as other goods are concerned different parts of the country may have differences in their supply and hence the average set sizes may vary. As an area of future research one can study the brand categorization process for fast moving consumer goods, electronic goods etc. cross classified by gender or economic groups etc.

\section{References:}

Belonax, J., A., Jr. (1979). Decision rule uncertainty, evoked set size, and task difficulty as a function of number of choice criteria and information variability. Advance Consumer Research. Ed. H. Keith Hunt. Provo, UT: Association for Consumer Research: 48-51.

Brisoux, J., E. \& Laroche, M. (1980). A Proposed Consumer Strategy of Simplification for Categorizing Brands Evolving Marketing thought for 1980.Eds. John H. Summey and Ronald D. Taylor. Carbondale, IL: Southern Marketing Association, 112-114.

Brown, J. J. \& Wildt, A. R. (1992). Consideration set measurement. Journal of the Academy of Marketing Science, 20(3): 235-243.

Campbell, B., M. (1969). The Existence and Determinants of Evoked Set in Brand Choice Behavior. Ph. D Dissertation, Columbia University.

Chintagunta, P., K. (1992). Estimating a multinomial probit model of brand choice using the method of simulated moments. Marketing science, 11(4): 386-407.

Church, N., J., Laroche, M. \& Rosenblatt, J., A. (1985). Consumer brand categorization for durables with limited problem solving: An empirical test and proposed extension of the Brisoux-Laroche model. Journal of Economic Psychology, 6: 231-253.

Cullen, F. \& Kingston, H. (2009). Analysis of rural and urban consumer behavior toward new food products using a food-related lifestyle instrument. Journal of Foods Service Business Research, 12(1): 18-41. 
Desai, K., K. \& Hoyer, W., D. (2000). Descriptive characteristics of memory-based consideration sets: influence of usage occasion frequency and usage location familiarity. Journal of Consumer Research, 27 (Dec): 309-323.

Desarbo, W. S. \& Jedidi, K. (1995). The spatial representation of heterogeneous consideration sets. Marketing Science, 14(3): 326-342.

Elrod, T. \& Keane. M., P. (1994). A factor-analytic model for representing the market structure in panel data. Journal of Marketing Research, 32(February): 1-16.

Guadangi, P., M. \& Little, J. D. C. (1983). A logit model of brand choice calibrated on scanner data. Marketing Science, 2 (3): 203-238.

Hauber, J. \& Kline, N., M. (1991). Adapting cut offs to the choice environment: The effects of attribute correlation and reliability. Journal of Consumer Research, 18(December): 346-357.

Hauser, J., R. \& Wernerfelt, B. (1990). An evaluation cost model of evoked sets. Journal of Consumer Research, 16 (March): 393-408.

Howard, J., A. (1963). Marketing Management, Analysis and Planning, Irwin.

Howard, J., A. (1977). Consumer Behaviour: Application of Theory, McGraw-Hill.

Howard, J., A. \& Sheth, J. N. (1969).The Theory of Buyer Behavior. New York: John Willey.

Jarvis, L. P. \& Wilcox, J. (1973). Evoked set size: some theoretical foundations and empirical evidence. In Combined Proceedings, ed. T.V. Greer Chicago: American marketing Association, 236-240.

Kardes, F., R., Gurumurthy, K., Murali, C. \& Ronald, J., D. (1993). Brand retrieval, consideration set composition, consumer choice, and the pioneering advantage. Journal of Consumer Research, 20 (June): $62-73$.

Kotler, P. (2002). Marketing Management. 10 ${ }^{\text {th }}$ Ed. 397.

Klenosky, D., B. \& Rethans, A., J. (1988). The formation of consumer choice sets: A longitudinal investigation at the product class level. Advances in Consumer Research. Ed. Michael J. Houston. Provo, UT: Association for Consumer Research, 13-17.

Laroche, M. \& Rosenblatt, J. (1983). Brand categorization strategies in RRB situations: Some empirical results. Advance in Consumer Research, 10: 549-554.

Maddox, R., N., Gronhaug, K., Homans, R., E. \& Fredrick, E. (1978). Correlates of information gathering and evoked set size for new automobile purchasers in Norway and the U.S. Advances in consumer Research Edition H. Keith Hunt. Provo, UT: Association for Consumer Research, 167-170.

Mehta, N., Rajiv, S. \& Srinivasan, K. (2003). Price uncertainty and consumer search: A structural model of consideration set formation. Marketing Science, 22(1): 58-84.

Myers, J., H. (1976). Benefit structure analysis: A new tool for product planning. Journal of Marketing, 40(October): 23-32.

Narayana, C., L. \& Markin, R., J. (1975). Consumer behaviour and product performance: An alternative conceptualization, Journal of Marketing, 39: 1-6.

Nedungadi, P. (1987). Formation and Use of a Consideration Set: Implications of Marketing and Research on Consumer Choice. PhD Dissertation, Gainesville, FL: University of Florida.

Nedungadi, P. (1990). Recall and consumer consideration sets: Influencing choice without altering brand evaluations. The Journal of Consumer Research, 17(3): 263-276.

Ratneshwar, S. \& Shocker, A., D. (1991). Substitution in use and the role of usage context in product category structures. Journal of Marketing Research, 28 (August): 281-295.

Roberts, J. (1989). A grounded model of consideration set size and composition. Advances in Consumer Research, 16: 749-757.

Roberts, J., H. \& Lattin, J., M., (1991). Development and testing of a model of consideration set composition. Journal of Marketing Research, 28(November): 429-440.

Roger, H. \& Hacfen, V. (2008). Latent consideration sets, and continuous demand systems. Marketing Letters, 41: 363-379.

Schiffman, L., G. \& Kanuk, L., L. (2007), Consumer Behaviour, Edition Ninth Edition.

Shari Waters, accessed on $12^{\text {th }}$ May, 2010 from http://retail.about.com/od/glossary/g/staple_goods.html.

Sharma, N., K., \& Srivastava, K. (2008). Brand extension: strategy for new product of introduction. Indian Journal of Marketing, 38(8): 33-39.

Siddarth, S., Buckling, R., E. \& Morrison. G., D. (1995). Making the cut: modeling and analyzing choice set restriction in scanner panel data. Journal of Marketing Research, 32(August): 255-266. 
Shocker, A., D., Ben-Akiva, M., Boccara, B. \& Nedungadi, P. (1991). Consideration set influences on consumer decision-making and choice: Issues, Models, and Suggestions. Marketing Letters, 2(3): 181-197.

Troye, S., V. (1984). Evoked set formation as a categorization process. Advances in Consumer research. Ed. Thomas C. Kinnear, Provo, UT: Association for Consumer Research: 180-186.

Vroomen, B., Franses, P., H., \& Nierop, E., V. (2004). Modelling consideration sets and brand choice using artificial neural network. European Journal of Operation research. 154(1): 1-19.

Wright, P. (1975).Consumer choice strategies: Simplifying vs. Optimizing. Journal of Marketing Research, 12 (February): 60-67.

Wright, P. \& Barbour, F. (1977). Phased Decision Strategies: Sequels to Initial Screening. Multiple Criteria decision Making: North Holland TIMS Studies in Management Science, M. Starr and M. Zeleny, eds. Amsterdam: North-Holland Publishing Company: 91-109. 